\title{
Remaining Technical Challenges and Future Plans for Oil-Free Turbomachinery
}

Christopher DellaCorte and Robert J. Bruckner

Glenn Research Center, Cleveland, Ohio 


\section{NASA STI Program . . . in Prof le}

Since its founding, NASA has been dedicated to the advancement of aeronautics and space science. The NASA Scientif $c$ and Technical Information (STI) program plays a key part in helping NASA maintain this important role.

The NASA STI Program operates under the auspices of the Agency Chief Information Off cer. It collects, organizes, provides for archiving, and disseminates NASA's STI. The NASA STI program provides access to the NASA Aeronautics and Space Database and its public interface, the NASA Technical Reports Server, thus providing one of the largest collections of aeronautical and space science STI in the world. Results are published in both non-NASA channels and by NASA in the NASA STI Report Series, which includes the following report types:

- TECHNICAL PUBLICATION. Reports of completed research or a major signif cant phase of research that present the results of NASA programs and include extensive data or theoretical analysis. Includes compilations of signif cant scientif $\mathrm{c}$ and technical data and information deemed to be of continuing reference value. NASA counterpart of peer-reviewed formal professional papers but has less stringent limitations on manuscript length and extent of graphic presentations.

- TECHNICAL MEMORANDUM. Scientif c and technical $f$ ndings that are preliminary or of specialized interest, e.g., quick release reports, working papers, and bibliographies that contain minimal annotation. Does not contain extensive analysis.

- CONTRACTOR REPORT. Scientif c and technical $\mathrm{f}$ ndings by NASA-sponsored contractors and grantees.
- CONFERENCE PUBLICATION. Collected papers from scientif $\mathrm{c}$ and technical conferences, symposia, seminars, or other meetings sponsored or cosponsored by NASA.

- SPECIAL PUBLICATION. Scientif c, technical, or historical information from NASA programs, projects, and missions, often concerned with subjects having substantial public interest.

- TECHNICAL TRANSLATION. Englishlanguage translations of foreign scientif $\mathrm{c}$ and technical material pertinent to NASA's mission.

Specialized services also include creating custom thesauri, building customized databases, organizing and publishing research results.

For more information about the NASA STI program, see the following:

- Access the NASA STI program home page at http://www.sti.nasa.gov

- E-mail your question via the Internet to help@ sti.nasa.gov

- Fax your question to the NASA STI Help Desk at 443-757-5803

- Telephone the NASA STI Help Desk at 443-757-5802

- W rite to: NASA Center for AeroSpace Information (CASI) 7115 Standard Drive Hanover, MD 21076-1320 


\section{Remaining Technical Challenges and Future Plans for Oil-Free Turbomachinery}

Christopher DellaCorte and Robert J. Bruckner

Glenn Research Center, Cleveland, Ohio

Prepared for the

Turbo Expo 2010

sponsored by the American Society of Mechanical Engineers (ASME)

Glasgow, Scotland, United Kingdom, June 14-18, 2010

National Aeronautics and

Space Administration

Glenn Research Center

Cleveland, Ohio 44135 
Level of Review: This material has been technically reviewed by technical management.

Available from

NASA Center for Aerospace Information 7115 Standard Drive

Hanover, MD 21076-1320
National Technical Information Service 5301 Shawnee Road Alexandria, VA 22312

Available electronically at http://gltrs.grc.nasa.gov 


\title{
Remaining Technical Challenges and Future Plans for Oil-Free Turbomachinery
}

\author{
Christopher DellaCorte and Robert J. Bruckner \\ National Aeronautics and Space Administration \\ Glenn Research Center \\ Cleveland, Ohio 44135
}

\begin{abstract}
The application of Oil-Free technologies (foil gas bearings, solid lubricants and advanced analysis and predictive modeling tools) to advanced turbomachinery has been underway for several decades. During that time, full commercialization has occurred in aircraft air cycle machines, turbocompressors and cryocoolers and ever-larger microturbines. Emerging products in the automotive sector (turbochargers and superchargers) indicate that high volume serial production of foil bearings is imminent. Demonstration of foil bearings in APU's and select locations in propulsion gas turbines illustrates that such technology also has a place in these future systems. Foil bearing designs, predictive tools and advanced solid lubricants have been reported that can satisfy anticipated requirements but a major question remains regarding the scalability of foil bearings to ever larger sizes to support heavier rotors. In this paper, the technological history, primary physics, engineering practicalities and existing experimental and experiential database for scaling foil bearings are reviewed and the major remaining technical challenges are identified.
\end{abstract}

\section{Introduction}

Turbomachinery built upon unconventional, Oil-Free, rotor support technologies has been maturing since the middle of the last century. During this period numerous advances in compliant surface gas bearings, electromagnetic bearings, materials, solid lubricants and analytical and computer based models have been achieved. New Oil-Free rotor system designs have been developed and deployed in ever increasingly complex and larger practical machines. The authors' organization, NASA, has driven much of the pioneering development and has made long and deep investments in OilFree technologies because of their uniquely intrinsic and enabling value to space power conversion and aeropropulsion turbomachinery systems (Refs. 1 and 2).

NASA relevant application examples include air cycle machines (ACM's) used for aircraft cabin environmental control systems, cryogenic turboexpanders and compressors, reusable long-life turbopumps, maintenance free auxiliary power units (APU's), aircraft propulsion engines, and closed Brayton cycle (CBC) turbine generators for space power. In addition several entirely new industries have been built upon the pioneering technology demonstrations. These include Oil-Free microturbines, fuel cell blowers, Oil-Free turbochargers and industrial air compressors. As Oil-Free products further penetrate industrial markets, it seems an appropriate time to explore, identify and articulate the remaining major technical challenges and questions in this field. In the following sections of this paper, Oil-Free technologies are reviewed and the current state of the art is presented. The major remaining technical challenges related to bearing scalability are explored and advanced approaches to hybridization of bearing technologies to overcome limitations are highlighted.

\section{Nomenclature}

$\begin{array}{ll}\text { ACM } & \text { Air Cycle Machine } \\ \text { APU } & \text { Auxiliary Power Unit } \\ \text { DN } & \text { bearing surface velocity parameter } \\ \text { W } & \text { shaft load } \\ \mu & \text { fluid viscosity } \\ \mathrm{W}_{\mathrm{LC}} & \text { load capacity at speed } \\ \mathrm{D} & \text { bearing performance coefficient }\left(\mathrm{lb} / \mathrm{in} .{ }^{3} / \mathrm{k}_{\mathrm{rpm}}\right) \\ \mathrm{L} & \text { bearing axial length (in.) } \\ \text { D } & \text { shaft diameter (in.) } \\ \mathrm{K}_{\mathrm{rpm}} & \text { shaft speed in thousands of rpm }\end{array}$

\section{Technology Background}

Foil bearings are self-acting, hydrodynamic fluid film bearings that use the ambient fluid, typically a gas, as their lubricant. In general, foil bearings are capable of supporting lightly loaded, high-speed rotating shafts. The lubricating fluid-film is generated by the viscous pumping action of the moving shaft or runner surface. The fluid film forms between the moving surface and a thin, flexible sheet metal foil layer that is supported by a series of spring foils. The foil layer facing the moving surface traps the hydrodynamic gas film and the supporting spring foils provide compliance, tolerance to misalignment and distortion and a host of other attributes such as damping (Ref. 3). Figure 1 shows a sketch of a typical bump style foil journal bearing.

There are two distinct types of foil gas bearings, journal and thrust bearings as depicted in Figure 2. Journal bearings support radial loads and thus control rotor orbit. Thrust bearings control axial motion. Though their geometry differs, both types of foil bearings operate under the same basic principles, namely that the moving surface relies on viscous action to drag fluid into the bearing generating hydrodynamic pressure that pushes the inner foil surface away from the shaft. 


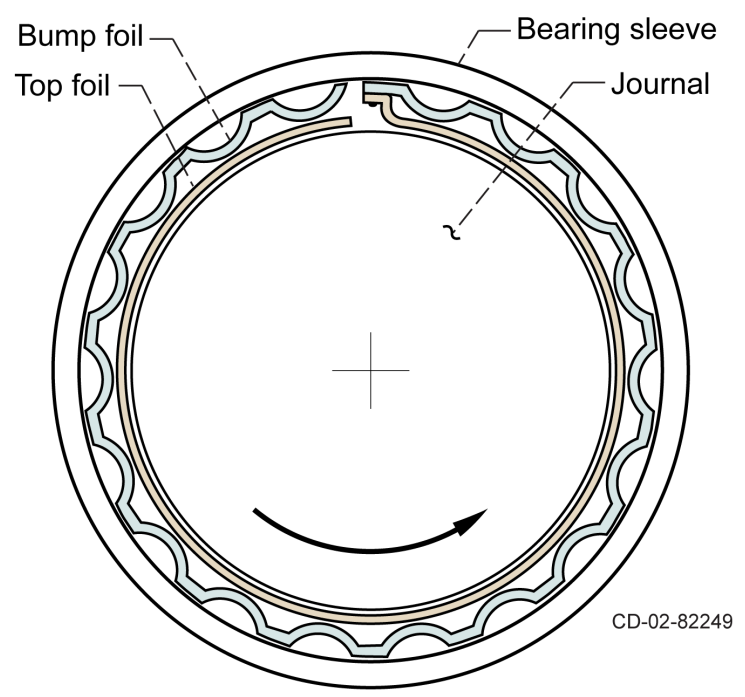

Figure 1.-Cross section view of simple radial foil bearing.

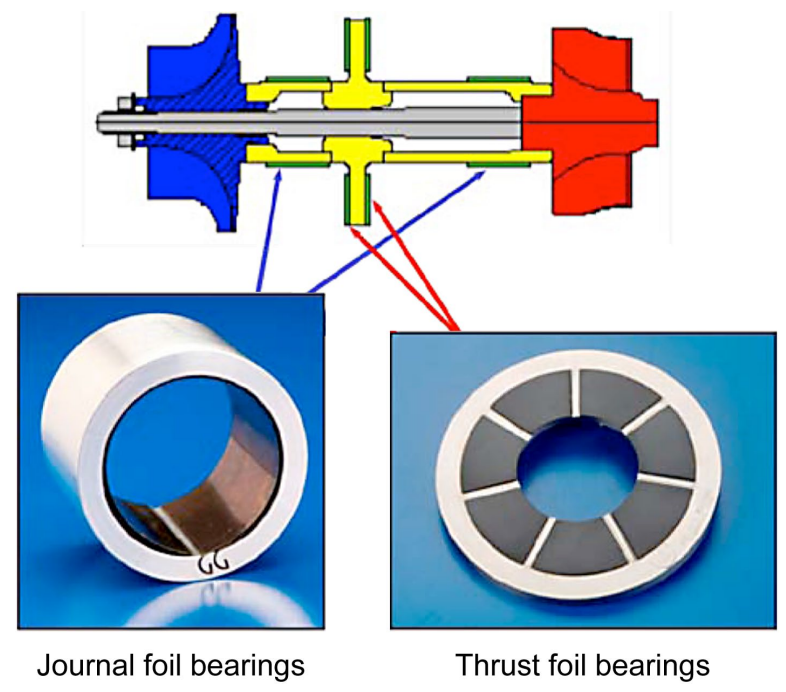

Figure 2.-Journal and thrust foil bearings used to control radial and axial shaft motion, respectively.

In turbomachinery systems, thrust loads can be minimized through careful sizing and design of aerocomponents and judicious selection of operating points. Since no commensurate approach exists for radial loads, scalability of journal bearings is critical to the extension of Oil-Free turbomachinery to larger machines. In addition, thrust bearing development and scalability has historically followed the advancement of journal bearings since they share similar basic underlying physics. While thrust bearings do present major challenges, the current paper solely focuses on journal bearings with the expectation that advancements in journal bearings will transition to thrust bearings.

In turbomachinery systems, thrust loads can be minimized through careful sizing and design of aerocomponents and judicious selection of operating points. Since no commensurate approach exists for radial loads, scalability of journal bearings is critical to the extension of Oil-Free turbomachinery to larger machines. In addition, thrust bearing development and scalability has historically followed the advancement of journal bearings since they share similar basic underlying physics. While thrust bearings do present major challenges, the current paper solely focuses on journal bearings with the expectation that advancements in journal bearings will transition to thrust bearings.

Since the ambient bearing cavity gas is used as the working fluid no dedicated lubrication system is needed. In essence, the gas takes the place of oil used in conventional bearings making foil bearings "Oil-Free." In addition, foil bearings also eliminate the use of rolling elements such as balls or rollers, which introduce their own restrictions on performance like DN speed limitations. Thus, among the major benefits of using foil bearings is their ability to run at high speeds and temperatures without an oil system and this leads to simpler, safer and often lower cost engineered systems (Ref. 1).

\section{Technological Development History}

The foil gas bearing was originally discovered within the tape recording industry. Early technologists seeking to drive magnetic tape over recording heads at ever-faster speeds found that recording performance degraded at high speeds because the tape began to float away and "lift-off" the heads. This floating phenomena was deemed a nuisance and Baumeister (Ref. 4) at IBM was the first to recognize it as a form of gas hydrodynamics and named it the "foil bearing problem" in reference to the flexible oil-lubricated bearings made from metal foils studied in Europe in the 1950s. His colleague, W.R. Gross, mathematically modeled the tape motion and envisioned a means to turn such a phenomenon into a practical bearing device for high-speed spindles. This was essentially a solution seeking a problem and Gross published his findings on such flexible gas bearing concepts in the literature (Ref. 4). Figure 3 shows a cross section of the earliest of foil bearings that resemble a shaft braced on three sides with a tape of metal foil held in place by spring-loaded rollers.

NASA and the Office of Naval Research (ONR) encouraged Gross to apply his bearing concept to support high speed gas circulators and compressor-turbines used to cool gas filled nuclear reactors in terrestrial and space applications (Ref. 5). In both of these cases, the primary need was for a bearing system capable of operating at high speeds and temperatures for extended periods without maintenance and with no possibility of any contamination of the flow stream with oil lubricants.

With significant financial support from the ONR and technical oversight from NASA, Gross and his colleagues demonstrated these recording tape inspired foil gas bearings were viable for high-speed rotor support. Among the very first applications was the $15 \mathrm{~kW}$ Brayton Rotating Unit (BRU) shown in Figure 5. 


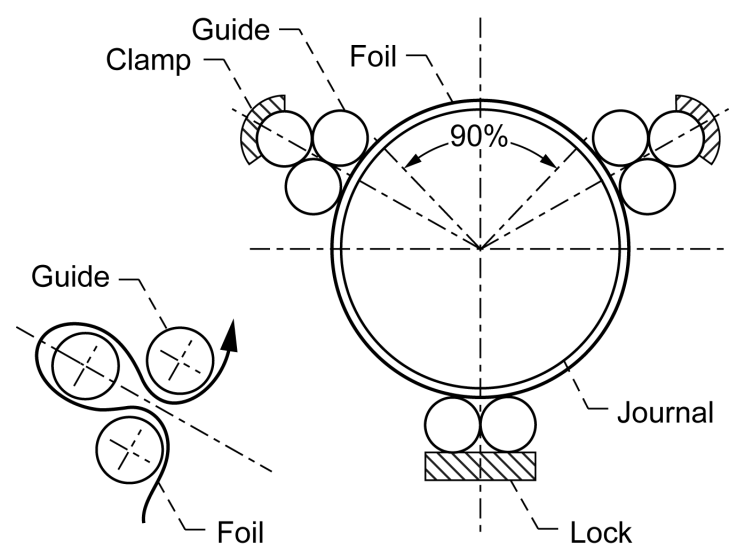

Figure 3.-Earliest foil bearings were inspired by magnetic tape/roller geometry and were used to replace rigid sleeve bearings in Brayton Rotating Unit (BRU) demonstrator (Ref. 5).

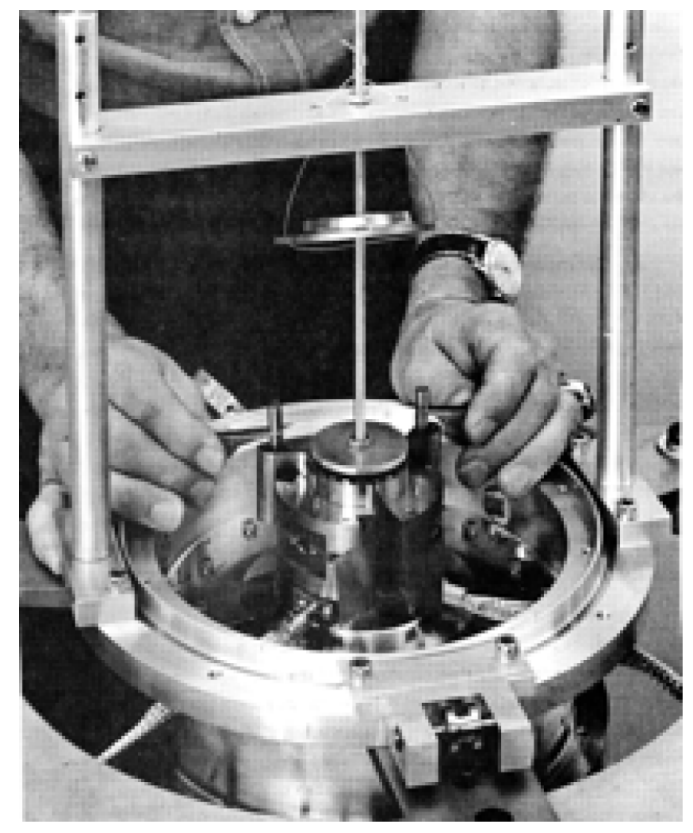

Figure 4.-Tape-type journal bearing under test.

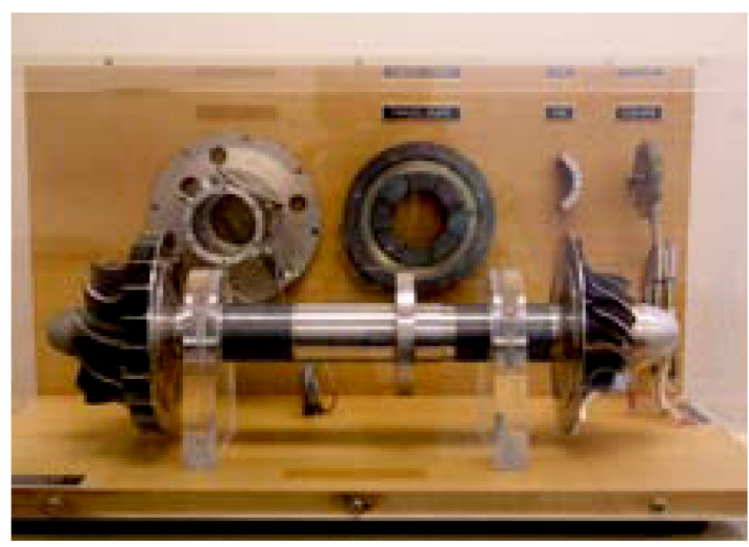

Figure 5.-15 kW Brayton Rotating Unit (BRU) turbine using foil bearings in place of rigid gas bearings.
This compressor-turbine machine had a shaft mounted electrical generator and was intended to demonstrate that long life, maintenance free power generation could be achieved using any heat source, be it nuclear or solar, that could supply sufficient hot gas to the turbine inlet. The BRU was originally designed to operate on rigid gas bearings but these proved too susceptible to particulate contamination, centrifugal and thermal shaft-bearing distortions and they lacked adequate damping to prevent excessive vibrations and rotordynamic instabilities.

The application of the foil bearing to the BRU overcame all of its rotor support related technological problems and resulted in a milestone game-changing demonstration. Following this accomplishment, every CBC power conversion system NASA has developed since has relied solely on foil bearings. Detailed reports were written and widely disseminated that described the design, modeling, manufacturing and testing of the foil gas bearings used to support the NASA turbine. Industrial recipients of the information then led foil bearing development for ACM's, turboexpanders, and APU's (Ref. 5).

Garret-AiResearch deployed foil bearings in commercial aircraft cabin pressurization turbomachines in the late 1960s. These very first fully commercialized Oil-Free machines revolutionized environmental control systems (ECS) for aircraft (Ref. 6). The foil gas bearings enabled completely maintenance free, Oil-Free cabin pressurization and air conditioning to modern aircraft without the possibility of oil fumes infiltrating the cabin, a problem common to jets in the 1950s and 60s. For several years, Garret-AiResearch enjoyed a growing market share owing to their unique and far superior technology. In the mid 1970s, Mechanical Technologies Incorporated (MTI) and Hamilton Standard developed a competing bump style foil bearing which was first deployed into ACM's for fighter aircraft then fully commercialized in DC-10 and other aircraft of the day.

In the 1970s, NASA heavily leveraged Department of Energy (DOE) funding to demonstrate, in concert with industry, a series of automotive gas turbines utilizing foil bearings. These engines placed unique demands on the foil bearings in that they had to run hotter and faster than the state-of-the-art that existed at the time. Hardware contracts were awarded to multiple companies and a vigorous in-house test program resulted in new high temperature solid lubricant coatings, improved bearing designs, bearing test rig facilities and an experience base that enabled closely controlled, value added contract oversight (Ref. 7). Though the automotive turbines did not enter production, they proved that small gas turbines could utilize foil bearings and that suitable high temperature materials and solid lubricant coatings could be engineered to survive the engine environment. Figure 6 shows an example of one of these test engines. Numerous reports detailing the foundational technologies were published and industrial demonstration programs, many funded by the DoD, followed. Notable examples include Oil-Free auxiliary power units (APU)'s for tanks and small aircraft (Ref. 8). 


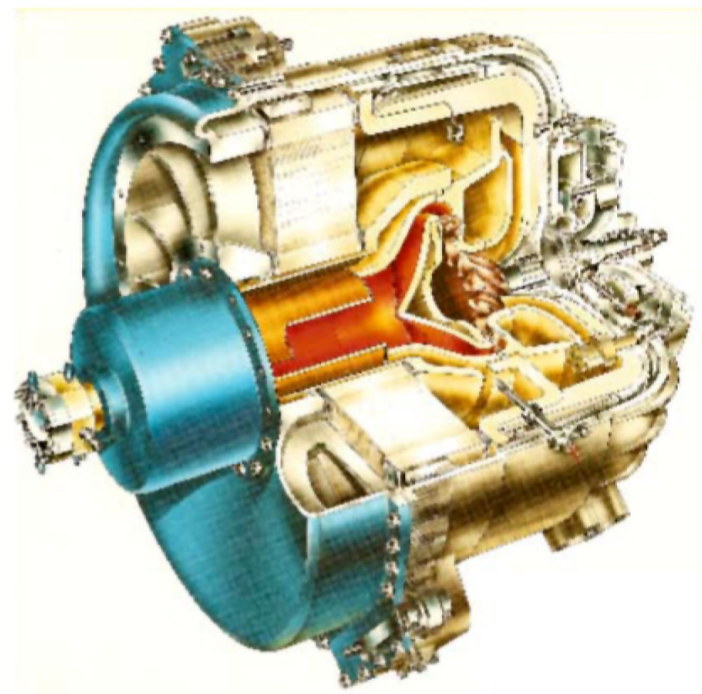

Figure 6.-Early automotive gas turbine using foil bearings for the high-speed core shaft proved the technology for combustion driven turbomachines.

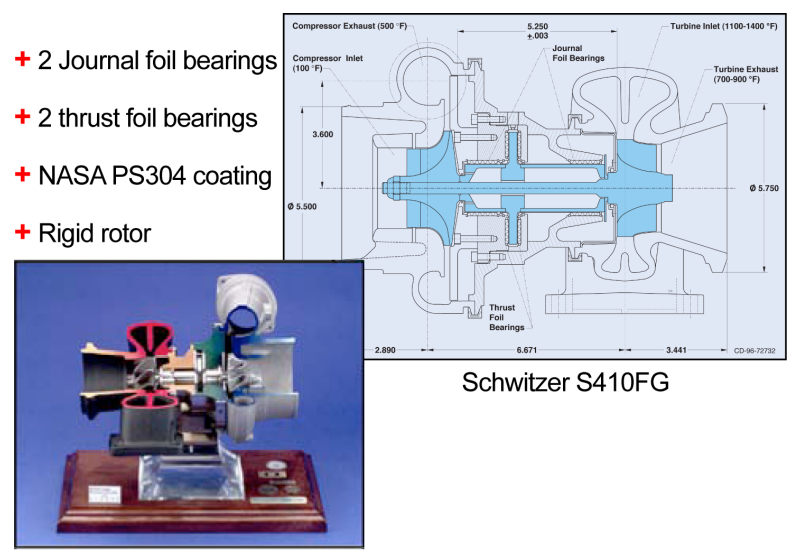

Figure 7.-Cutaway photograph of the NASA Oil-Free turbocharger.

Interestingly, technologists working on these demonstration projects at Honeywell (Garret-AiResearch) in the 1980s took early retirements and started a new business to commercialize small efficient, foil bearing supported turbomachinery. This company, NoMac Industries, was bought by investors and eventually became Capstone Turbines, now the world's foremost manufacturer of Oil-Free microturbines (Ref. 9). Foil bearings were selected for their long life and low maintenance characteristics. In the early 1990s, Capstone relied on the information provided in NASA reports on high temperature foil bearing coatings and consultations with NASA researchers to develop their first successful engines and continues to collaborate on advanced engine technology (Ref. 10). Capstone has evolved their product line that includes power generation turbines from 30 to over $200 \mathrm{~kW}$ and has sold over 4000 units worldwide.
The need for robust and reliable low temperature turbomachinery, such as reusable cryogenic rocket engine turbopumps, led to NASA funded study, design and demonstration efforts for foil bearings and externally pressurized hydrostatic bearings. Test rigs were built and bearings were tested in liquid nitrogen, water and liquid hydrogen. The results were widely reported and the basic technologies formed the basis of numerous cryogenic turboexpanders and turbocompressors now in commercial use (Ref. 11).

Through these development and demonstration projects, the basic Oil-Free technology matured. Foil bearing performance improved, test capabilities and methods were established and suitable bearing materials and tribological coatings were proven. One aspect that had been largely lacking was a formalized, widely disseminated development method for designing and building a new Oil-Free machine. The Oil-Free turbocharger project served to fill this void.

The Oil-Free turbocharger demonstration project was triggered by the confluence of four factors: 1) the doubling of foil bearing load capacity via better structural design; 2) the emergence of high temperature solid lubricant coatings tailored for foil bearings; 3 ) the availability of foil bearing test rigs to verify bearing performance; and 4 ) the establishing of a four step hardware development process for risk mitigation.

With these four factors as a backdrop, work began in earnest in 1995 with NASA's Oil-Free turbomachinery team leading an industry effort that combined the foil bearings of Mechanical Technology Incorporated (later the effort was transferred to Mohawk Innovative Technologies), the turbocharger technology of Schwitzer Corporation (now BorgWarner Automotive), and the diesel technology of Caterpillar Corporation. Under this project, long-life foil bearings were demonstrated at temperatures over $650{ }^{\circ} \mathrm{C}$, and to speeds of $120,000 \mathrm{rpm}$. Further, a straightforward four-step development process was proven to carry new turbomachines supported on foil bearings from concept to system level demonstration with well-managed risks. The Oil-Free turbocharger, shown in Figure 8, was demonstrated in early 1999 and well publicized through magazine articles, peer reviewed journal papers and conference proceedings (Ref. 12).

The pathfinder turbocharger spurred industrial development programs in the US and abroad. To help meet these program needs, reports have been written that document foil bearing design and manufacturing techniques (Refs. 13 and 14). The patent literature captures the current state-of-the-art well by detailing the first known production patent for an Oil-Free turbocharger (Ref. 15). Further turbocharger development in Korea has quantified that Oil-Free turbochargers exhibit a significant reduction in friction losses than conventional machines, up to 10 percent overall efficiency improvements (Ref. 16).

The development of turbochargers signifies that many important fundamental milestones for Oil-Free turbomachinery have been realized. Foil bearing manufacturing methods, and solid lubricant coatings with long-life at low and high temperatures have been proven. Though still maturing, commercial 
U.S. Patent Mar. 5, 20102 Sheet 1 of $16 \quad$ US 6,353,273 B1

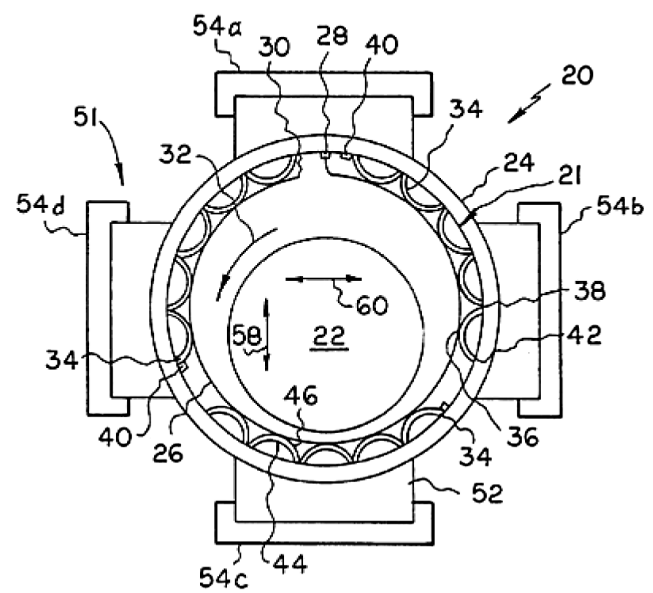

Figure 8.-Early hybrid foil-magnetic bearing concept that nests the foil bearing inside electromagnetic coils to create a "smart" bearing (Ref. 22).

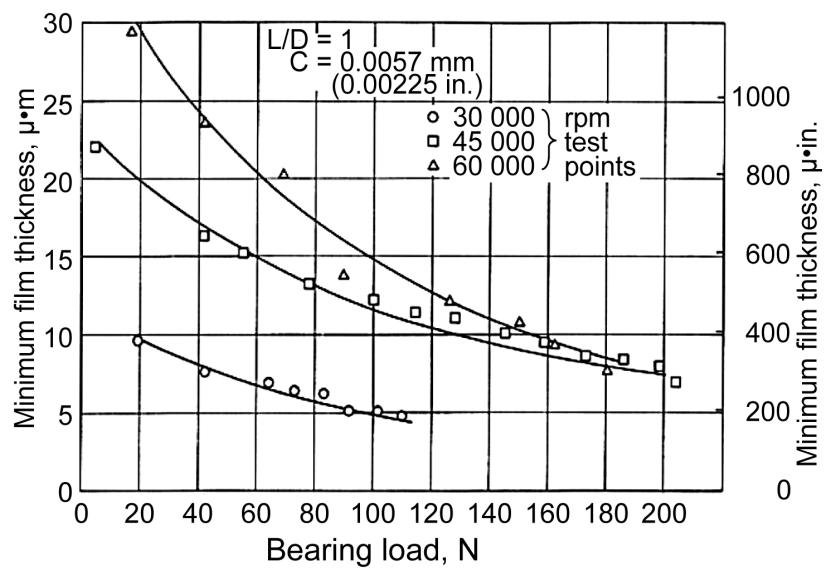

Figure 9.-Fluid film thickness versus load at varying speeds (Ref. 7). Smaller films can be sustained at lower speeds due to reduced thermal stresses on the bearing.

rotordynamic modeling tools and software packages exist that reasonably predict critical speeds, bearing properties and shaft dynamic behavior for foil bearing supported systems (Refs. 17 and 18). Lastly, a formalized, four-step method to implement a new rotor system has been verified as evidenced by the success of the Oil-Free turbocharger demonstration. Using this new level of understanding, commercial manufacturers have greatly extended to breadth and scope of machines operating Oil-Free and a number of intriguing new hybrid technologies have been brought forth.

In Asia, several manufacturers produce Oil-Free compressors and blower product lines. Industry markets machines ranging in size from 50 to $500 \mathrm{hp}$ that compete very well in the commercial air-handling marketplace. These machines are electrically driven, require no maintenance and can be installed at the point where the air is needed, thus eliminating the need for elaborate and expensive air piping systems prevalent in older factories. Such direct drive machines are far more energy efficient than traditional compressors and blowers and eliminate the need for a speed increasing gearbox and the potential for oil contamination of products and factories (Ref. 19). Like ACM's, such machines utilize conventional foil bearings (35 to $75 \mathrm{~mm}$ diameter) and polymer based foil coatings to support rotors that weigh up to about $1000 \mathrm{~N}$. For larger rotors, either larger bearings or a more hybridized approach is required.

As rotors become heavier and bearings become larger, several characteristics of foil bearings present challenges. Among these are high start torque requirements, limited damping and limited low speed load capacity (Ref. 20). Recent work with large (76 mm diameter) journal bearings operating under high static loads (39 $\mathrm{kPa})$ has shown that durable low friction coatings and careful minimization of spring preload forces can allow bearings to survive even low shaft acceleration during prolonged start-up periods. Notwithstanding, long-term applications of large foil bearings for heavy rotors could benefit from hydrostatic or electromagnetic load sharing, especially during low speed operation.

An early demonstration of such a hybrid approach included the side-by side demonstration of a large (100 mm diameter) foil-magnetic bearing (Ref. 21). Such concepts have been patented (Refs. 22 and 23) and recent demonstrations indicate that this technology marriage is more capable than either bearing technology alone. Hybridization leads to a "smart" bearing in which the rotor static weight loads can be relieved and active damping can be added via electromagnetics (Ref. 24). Figure 9 depicts the hybrid 'smart" bearing approach.

While externally pressurized hydrodynamic foil and more conventional rigid surface gas bearings are an old concept (Ref. 25), recent demonstrations show that heavy rotors using large foil bearings (100 mm diameter) can be augmented with integral, pressurized air supply (Ref. 26). In this work, as expected, the augmentation air enabled essentially friction free start-up and elimination of foil surface wear. For this particular hybrid bearing which was not optimized for stability, at higher speeds, the hydrostatic bearing component needed to be curtailed to prevent pneumatic hammering and whirl instabilities. Nonetheless, these examples clearly show a path to the Oil-Free support of heavy rotors but highlight the more fundamental question concerning the identification of physical limits to foil gas bearing size, namely scalability. The following section outlines the dominant physical principles that appear to influence the scalability of passive foil gas bearings. That is, bearings that do not incorporate active clearance and thermal management controls, electromagnetic or hydrostatic augmentation or other "smart" features. 


\section{Bearing Scalability}

Foil bearings rely upon a thin (typically less than $10 \mu \mathrm{m}$ ) gas film to prevent rubbing contact between the foils and their mating surface (the shaft or thrust runner) (Ref. 7). This film thickness is determined by the operating speed (surface velocity), gas properties (viscosity) and load.

$$
\mathrm{h}=f(\mathrm{DN}, \mathrm{W}, \mu)
$$

In general, the functional relationship mirrors the Stribeck or Hersey number

$$
\mathrm{h}=f(\mu \mathrm{DN} / \mathrm{W})
$$

in which increases in speed or viscosity lead to increased film thickness and increasing load results in decreasing film thickness. Practical operating film thicknesses, however, are bounded by other factors.

A comprehensive experimental effort conducted in the 1970s led to measurements of the fluid film thickness for a Generation I bump foil bearing operating at varying loads, speeds, aspect ratios and preload levels (Ref. 7). In this work, capacitance type probes were embedded into the rotating shaft operating against a foil bearing enabling the direct measurement of film thickness. The results showed that the minimum film thickness (where useful pressure is generated in a bearing) varied only between 5 and $25 \mu \mathrm{m}$ depending upon load. Increased speeds led to increased minimum film thickness as expected but also had an ancillary effect. Higher speed operation resulted in a larger minimum sustainable film thickness than that observed for lower speeds as shown in the following figure. At high speeds and loads excessive power loss led to thermally limited bearing load capacity.

This result, which has been corroborated through subsequent modeling and experimental work, shows that the film thickness is constrained in both the thick and thin film regimes. High shear rates, increased viscous losses and highly localized heating characterize thin films. Since typical foil bearing materials like nickel based superalloys have high thermal expansion coefficients and low thermal conductivities, localized heating leads to foil distortion, rupture of the gas film and bearing failure. Extensive research has shown that poor thermal management is a leading cause of foil bearing failure particularly at high speeds and thin films (Refs. 27 and 28). In this context, one can see that the practical minimum sustainable film thickness actually increases at very high speeds due to thermal effects thus limiting the practical and achievable hydrodynamic pressure unless special care or more active cooling systems are employed. The behavior at low loads is equally interesting in that films thicker than about $25 \mu \mathrm{m}$ cannot be achieved. The reasons for this are many faceted. Due to the low gas viscosity, the hydrodynamic effect results in useful pressure rise only for thin films. Further, should the film thickness rise appreciably above $25 \mu \mathrm{m}$, pressure loss through side leakage from the bearing effectively bleeds the high pressure region, again, unless more actively controlled bearing geometry designs are employed. In light of these constraints, it is unsurprising that engineering film thicknesses are bounded between 5 and $25 \mu \mathrm{m}$.

It is important to remind the reader that unlike rigid bearings, foil bearings have no true clearance. At rest, the foil surface is spring preloaded against the journal. Above the liftoff speed, the hydrodynamic pressure deflects the foil and its elastic supporting structure away from the journal surface resulting in a hydrodynamic film thickness one would normally compare to a "clearance" for a rigid bearing thus establishing an eccentricity. Because of these subtle differences between foil bearings and conventional gas bearings the authors find that considering bearing behavior in terms of lubricating film thickness to be a rational approach to understanding foil bearings.

The magnitude of the film thickness has an important impact on bearing scalability. Foil bearings must operate against a moving shaft or runner surface, and thus the film thickness and the surface velocity dictate the useful pressure and load capacity. Since the film thickness is limited, only higher speeds provide a potential path to higher pressures and the possibility of supporting heavy rotors. When using conventional rigid, fixed clearance bearings at very high speeds, centrifugal shaft growth can overwhelm the design clearance, but for compliant surface foil bearings, shaft growth is accommodated by the elasticity of the support structure. Nonetheless, maximum surface velocity in a bearing is limited by practical engineering concerns.

Bearing surface velocity is constrained by structural material specific strength. As a shaft (or thrust bearing runner) rotates, centripetal forces build proportional to the product of the radius and the square of the rotational velocity $\left(\mathrm{r} \omega^{2}\right)$. These forces result in stresses and strains that act upon the shaft causing geometrical growth and distortions. Further, at sufficiently high speeds the stresses can exceed allowable materials limits and cause permanent deformation and possibly bursting. While careful material selection and structural design can minimize these effects, practical purposes using conventional engineering materials, accepted practice limits are well known.

In turbomachinery, a frequently understood practical limit for uncooled high temperature rotating structures is the "maximum exit rim speed" for axial flow compressors, taken to be approximately $450 \mathrm{~m} / \mathrm{s}$ (Ref. 29). For bearing technology, an analogous limit, largely driven by the same centripetal loading phenomena is the DN limit where $\mathrm{D}$ is the shaft diameter in $\mathrm{mm}$ and $\mathrm{N}$ is the rpm. For rolling element bearings the maximum DN while retaining adequate fatigue life is about 3 million using highly specialized bearings, lubricants and cooling methods. For oil lubricated hydrodynamic bearings the limit is not quite as well established as unacceptable drag losses typically preclude DN values above 2 million $(100 \mathrm{~m} / \mathrm{s})$. However, since such bearings rely upon a rotating shaft that has a surface velocity limit of $450 \mathrm{~m} / \mathrm{s}$, one can translate this value directly into an equivalent DN of 
8.6 million. However, such a simplistic calculation would place a foil bearing in the heart of a machine's fluid flow path (turbomachinery) potentially blocking mass flow and limiting machine power output. Since turbomachines, especially those employing axial flow components, are sized based upon a minimum flow path area structural elements like bearings and bearing struts must fit within the aforementioned rim diameter. With this in mind, a more realistic bearing DN (based upon the bearing diameter) is half the rim exit speed of $225 \mathrm{~m} / \mathrm{s}$ or a $\mathrm{DN}$ of 4.3 million. These values ( 3 and $4.3 \mathrm{MDN}$ ) are reasonably consistent and give rise to the rationale that practical foil bearing speeds are limited to below this range.

\section{Scalability Example}

Foil bearing load capacity considerations (based upon maximum speed and minimum sustainable film thickness considerations) allow the estimation of other bearing properties that help set reasonable scalability limits for Oil-Free technologies. For instance, using the widely accepted "Rule-of-Thumb" (ROT) for foil bearing load capacity, the maximum load that can be supported by a journal foil bearing is (Ref. 3):

$$
\mathrm{W}_{\mathrm{LC}}=\mathrm{D}(\mathrm{LD}) \mathrm{DK}_{\mathrm{rpm}}
$$

A few specific examples follow to illustrate the current understanding of bearing scalability effects.

A $100 \mathrm{~mm}$ diameter $(D=1, L / D=1)$ bearing operating at $20,000 \mathrm{rpm}$ (2 MDN) would be expected to carry about 1 , lb $(\sim 6 \mathrm{kN})$ maximum load. Bearings of this size have been produced and tested. Experimental data from the literature (Ref. 21) corroborates the load capacity ROT estimates for such bearings and is considered within current state-of-the-art.

Extending the ROT approach, a bearing twice the diameter and twice the length $(200 \mathrm{~mm}$ ) would support eight times the load (10000 lb, $4800 \mathrm{kN})$ and be operating at approximately the previously established DN speed limit (4 million). To assess if such a bearing is reasonable, an estimate can be made of the machine size and rotor weight that could be supported with two (fore and aft) such bearings.

Experiments with bearings ranging from 35 to $75 \mathrm{~mm}$ in diameter, have shown that deadweight static shaft loads must be less than $55 \mathrm{kPa}$ (8 psi) to permit manageable start-up torque and ensure long cyclic life (Refs. 20 and 30). Typical static loads for Oil-Free machines are much lower $14 \mathrm{kPa}$ ( $2 \mathrm{psi}$ ). Based upon these static load (14 to $55 \mathrm{kPa}$ ) considerations alone, the $100 \mathrm{~mm}$ diameter journal bearings used in the above example (two per rotor) can support rotors from 300 to $1200 \mathrm{~N}$ (64 to $256 \mathrm{lb}$ ). Rotors of this size are typical for air compressors in the 75 to $400 \mathrm{~kW}$ (100 to $500 \mathrm{hp)} \mathrm{range} \mathrm{and}$ small business class turbofan engines $(1,000 \mathrm{lb}, 5000 \mathrm{~N}$ thrust levels).

$200 \mathrm{~mm}$ diameter bearings, slightly beyond the current state-of-the-art, operating with a modest static load $(14 \mathrm{kPa})$ could support a rotor weighing from 2400 to $9800 \mathrm{~N}$ (496 to
$1988 \mathrm{lb})$. Rotors of this size class and rotational speed are typical for large gas compressors and low-pressure spools for medium thrust class $(20,000 \mathrm{lb}, 100 \mathrm{kN})$ turbine engines.

The purpose of these bearing sizing calculations is to show that based upon load capacity alone, conventional foil bearings appear capable of supporting large turbomachinery. These load capability estimates, however, are quite simplified and ignore other major constraints such as bearing stiffness and damping capabilities. The estimates also ignore other issues such as manufacturability of physically large and flexible structures. Such considerations cannot realistically be assessed without validation experiments. Another major concern facing scalability of foil bearings is that while load capacity grows with the square of the shaft diameter, bearing requirements such as shaft dynamic loads often scale with rotating mass (a volume characteristic) that grows with the diameter cubed. In other words, load capacity is not likely the limiting factor.

\section{Advanced Technology Needs}

Compared to oil lubricated bearings, foil gas bearings are characterized by relatively low levels of stiffness and damping, typically an order of magnitude lower. This behavior is largely due to the low gas viscosity and modest hydrodynamic film pressures that result from the operating conditions. Put another way, foil gas bearings are an appropriate rotor support technology for high-speed, lightly loaded rotors that benefit from the elimination of traditional oil systems and their complexities. Thus, a rotor design may be adequately supported with respect to load capacity but be unworkable due to inadequate bearing dynamic properties. To meet the challenges of heavy aerospace rotors with significant destabilizing forces and stringent orbit control requirements, conventional foil gas bearing technology alone is likely to be insufficient. Hybrid approaches in which foil bearing technology is combined with augmentation technology will likely be needed in larger Oil-Free rotor support systems.

Hybridization approaches utilizing low speed load sharing via hydrostatic gas pressurization is an attractive option. Such technology is readily available, scalable to large bearings and heavy rotors and adds little complexity. Such pressurization, however, must be phased out at higher speeds to avoid pneumatically driven instabilities. Further, such an approach requires a compressed air supply and offers little promise for improved stiffness and damping capability as well as active control.

Combining active electromagnetic technology with foil gas bearings offers many advantages. Such a "smart" bearing can unload the shaft weight during start-up and provide damping capabilities when rotordynamically required. Further, using the electromagnetic aspect of the hybrid bearing as the secondary support may reduce these device's size and electrical consumption to a more practicable level. Properly implemented, the bearing could also function as a shaft starter motor and integral starter generator. The success of purely magnetic 
bearing supported systems in land based compression machines demonstrate that hybrid smart bearings have real potential for more advanced applications. Future systems may well be capable of "active in-situ" diagnostics (tracking unbalance, shaft crack detection, seal degradation, etc.).

\section{Summary}

NASA's intrinsic need for technologies capable of supporting high speed rotors for power generation, propulsion and fluid handling for aeronautics and space missions has been a driving force in the development and proliferation of Oil-Free technologies. Technological commercialization has been achieved in small high-speed, lightly loaded applications like aircraft ACM's, cryogenic turboexpanders, blowers and compressors. Demonstration in APU's, turbochargers and full commercialization in microturbines has occurred. For these applications, bearing sizes of $100 \mathrm{~mm}$ diameter or less have been sufficient and the use of hybrid active controlled bearings unnecessary.

First principles based scaling suggests that structural limitations preclude bearing size (DN) growth much beyond 4 MDN unless hybridization of foil air bearings and active electromagnetic devices is realized. These technologies must also be applied to thrust bearings and proven via bearing and system demonstrations. With the adoption of such approaches, large heavy and high power rotating systems may be developed.

\section{References}

1. DellaCorte, C. and Valco, M.J., "Oil-Free Turbomachinery Technology for Regional Jet, Rotorcraft and Supersonic Business Jet Propulsion Engines,” Proceedings of the 2003 ISABE Conference, Cleveland, OH, AIAA-2003-1182.

2. Lucero, J.M., and DellaCorte, C., "Oil-Free Rotor Support Technologies for Long-life, Closed Cycle Brayton Turbines," Proceedings of the AIAA $2^{\text {nd }}$ International Energy Conversion and Engineering Conference (IECEC), pp. 1583-1591, Providence, RI, Aug. 2004.

3. DellaCorte, Christopher and Valco, Mark J., "Load Capacity Estimation of Foil Air Journal Bearings for Oil-Free Turbomachinery Applications,” Tribology Transactions, Vol. 43, No. 4, pp. 795-801, Oct. 2000.

4. Gross, W.A., "Film Lubrication-V. Infinitely Long Incompressible Lubricating Films of Various Shapes,” IBM Research Report RJ 117-5, pp. 69-70, Oct. 1958.

5. Licht, L., and Branger, M., "Design, Fabrication, and Performance of Foil Journal Bearings for the Brayton Rotating Unit,” NASA Contractor Report CR-2243, Jul. 1973.

6. Klaass, R.F., and DellaCorte, C., "The Quest for Oil-Free Gas Turbine Engines," Proceedings of the Power Systems Conference, New Orleans, LA, SAE Paper 2006-01-3055, Nov. 2006.

7. Ruscitto, D., McCormick, J., and Gray, S., "Hydrodynamic Air Lubricated Compliant Surface Bearing for an Automotive Gas Turbine Engine: I-Journal Bearing Performance,” NASA CR-135368, 1978.
8. Suriano, F.J., 1981, “Gas Foil Bearing Development Program,” U.S. Air Force Report Number AFWAL-TR-812095.

9. Kolanowski, B.F., Guide to Microturbines, Marcel Dekker, Ch. 1, pp. 1-15, 2004.

10. Lubell, D., DellaCorte, C., and Stanford, M.K., "Test Evolution and Oil-Free Engine Experience of a High Temperature Foil Air Bearing Coating,” Proceedings of GT2006: ASME Turbo Expo 2006, May 8-11, 2006, Barcelona, Spain, GT2006-90572.

11. Walton, J.F., and Heshmat, H., "Compliant Foil Bearings for Use in Cryogenic Turbopumps,” NASA CP-3282, Vol. 1, Sep. 1994, pp. 372-381.

12. Heshmat, Hooshang; Walton, II, James F.; DellaCorte, Christopher; Valco, Mark, "Oil-Free Turbocharger Demonstration Paves Way to Gas Turbine Engine Applications," presented at the International Gas Turbine \& Aeroengine Congress \& Exhibition sponsored by the American Society of Mechanical Engineers, Munich, Germany, May 8-11, 2000, 2000-GT-620.

13. DellaCorte, C., Radil, K.C., Bruckner, and Howard, S.A., "Design, Fabrication, and Performance of Open Source Generation I and II Compliant Hydrodynamic Gas Foil Bearings,” NASA/TM-2007-214691, ARL-TR-4102, and STLE Tribology Transactions, Vol. 51, pp. 254-264, 2008.

14. Dykas, B., Bruckner, R.J., DellaCorte, C., Edmonds, B.J., and Prahl, J.M., "Design, Fabrication and Performance of Foil Gas Thrust Bearings for Microturbomachinery Applications,” NASA/TM-2008-215062, ASME Paper GT200850377, and ASME Journal of Engineering for Gas Turbines and Power, Vol. 131, pp. 012301-1 to 012301-8, Jan. 2009.

15. LaRue, G.D., Kang, S.G. and Wick, W. (2006), "Turbocharger with Hydrodynamic Foil Bearings," U.S. Patent $1,108,488$.

16. Lee, Y.B., Park, D.J., and Kim, C.H.; "Stability and Efficiency of oil-Free Turbocharger with Foil Bearings for SUV, SAE paper 08SFI-0083, 2008.

17. Howard, S.A., Bruckner, R.J., DellaCorte, C., and Radil, K.C.: "Preliminary Analysis for an Optimized Oil-Free Rotorcraft Engine Concept," NASA/TM-2008-215064, ARLTR-4398, Proceedings of the American Helicopter Society, AHS Forum 63, Virginia Beach, VA, May 2007

18. Howard, S.A.: "Rotordynamics and Design Methods of an Oil-Free Turbocharger," NASA/CR-1999-208689, Jan. 1999.

19. Kim, K.S.; "An Experimental Study on the Performance of Air Foil Thrust Bearing for Application to Turbomachinery," Ph.D. dissertation, Korean Advanced Institute of Science and Technology, Daejon, Korea, Dec. 2006.

20. Radil, K.C., and DellaCorte, C.: "Foil Bearing Starting Considerations and Requirements for Rotorcraft Engine Applications," Army Research Report ARL-TR-4873, Aug. 2009.

21. Swanson, E.E., Heshmat, H., and Walton, J.F. II: "Performance of a Foil-Magnetic Hybrid Bearing," Journal of Engineering Gas Turbines Power, Vol. 124, Issue 2, pp. 375-383, Apr. 2002.

22. Nadjafi, R.H.: "Hybrid Foil/Magnetic Bearing," U.S. Patent 6,135,640, Oct. 2000.

23. Heshmat, H., Chen, M., and Walton, J.F., III: "Hybrid FoilMagnetic Bearing,” U.S. Patent 6,353,273, Mar. 2002. 
24. Lee, Y.B., Lee S.H., and Kim, S.J.: "Vibration Control and Low Power Consumption of the Combined Smart Bearings," Proceedings of the $4^{\text {th }}$ World Tribology Congress 2009, Kyoto Japan, Sep. 6-11, 2009, paper F-223.

25. Gross, W.A., Gas Film Lubrication, John Wiley and Sons, New York, NY, pp. 138-114, 1962.

26. Daejong Kim, Donghyun Lee, "Design of three-pads hybrid air foil bearing and experimental investigation on static performance,” in print, ASME Journal of Engineering for Gas Turbines and Power, 2009.

27. Radil, K.C., and Zeszotek, M., “An Experimental Investigation Into the Temperature Profile of a Compliant Foil Air bearing," NASA/TM-2004-213100 and ARL-TR-3200, May 2004.
28. Dykas, B., and Howard, S.A., "Journal Design Considerations for Turbomachine Shafts Supported on Foil Air Bearings,” STLE Tribology Transactions, Vol. 47, pp. 508-516, 2004.

29. Mattingly, J.D., "Elements of gas Turbine Propulsion," Ch. 9, and p. 663, McGraw-Hill, New York, NY, 1996.

30. DellaCorte, C., Valco, M.J., Radil, K.C., Heshmat, H., and Lukaszewicz, V.L., "Performance and Durability of High Temperature Foil Air Bearings for Oil-Free Turbomachinery," NASA/TM-1999-209187, Nov. 1999, Tribology Transactions, Vol. 43, No. 4, pp. 774-780, Oct. 2000. 


\begin{tabular}{|c|c|c|}
\hline \multicolumn{2}{|c|}{ REPORT DOCUMENTATION PAGE } & $\begin{array}{l}\text { Form Approved } \\
\text { OMB No. 0704-0188 }\end{array}$ \\
\hline \multicolumn{3}{|c|}{ 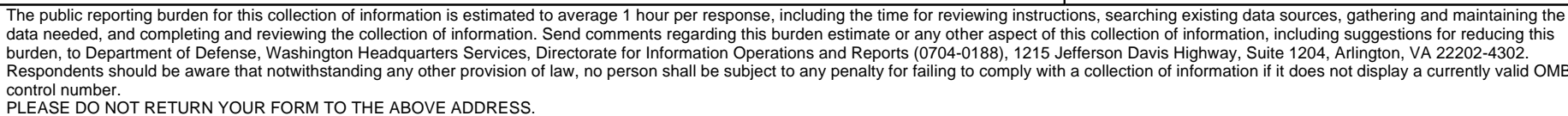 } \\
\hline $\begin{array}{l}\text { 1. REPORT DATE (DD-MM-YYYY) } \\
01-08-2010\end{array}$ & $\begin{array}{l}\text { 2. REPORT TYPE } \\
\text { Technical Memorandum }\end{array}$ & 3. DATES COVERED (From - To) \\
\hline \multirow{3}{*}{\multicolumn{2}{|c|}{$\begin{array}{l}\text { 4. TITLE AND SUBTITLE } \\
\text { Remaining Technical Challenges and Future Plans for Oil-Free Tur }\end{array}$}} & 5a. CONTRACT NUMBER \\
\hline & & 5b. GRANT NUMBER \\
\hline & & 5c. PROGRAM ELEMENT NUMBER \\
\hline \multirow{3}{*}{\multicolumn{2}{|c|}{$\begin{array}{l}\text { 6. AUTHOR(S) } \\
\text { DellaCorte, Christopher; Bruckner, Robert, J. }\end{array}$}} & 5d. PROJECT NUMBER \\
\hline & & 5e. TASK NUMBER \\
\hline & & $\begin{array}{l}\text { 5f. WORK UNIT NUMBER } \\
\text { WBS } 877868.02 .07 .03 .01 .01 .04\end{array}$ \\
\hline \multicolumn{2}{|c|}{$\begin{array}{l}\text { 7. PERFORMING ORGANIZATION NAME(S) AND ADDRESS(ES) } \\
\text { National Aeronautics and Space Administration } \\
\text { John H. Glenn Research Center at Lewis Field } \\
\text { Cleveland, Ohio 44135-3191 }\end{array}$} & $\begin{array}{l}\text { 8. PERFORMING ORGANIZATION } \\
\text { REPORT NUMBER } \\
\text { E-17383 }\end{array}$ \\
\hline \multirow{2}{*}{\multicolumn{2}{|c|}{$\begin{array}{l}\text { 9. SPONSORING/MONITORING AGENCY NAME(S) AND ADDRESS(ES) } \\
\text { National Aeronautics and Space Administration } \\
\text { Washington, DC 20546-0001 }\end{array}$}} & $\begin{array}{l}\text { 10. SPONSORING/MONITOR'S } \\
\text { ACRONYM(S) } \\
\text { NASA }\end{array}$ \\
\hline & & $\begin{array}{l}\text { 11. SPONSORING/MONITORING } \\
\text { REPORT NUMBER } \\
\text { NASA/TM-2010-216762 }\end{array}$ \\
\hline \multicolumn{3}{|c|}{$\begin{array}{l}\text { 12. DISTRIBUTION/AVAILABILITY STATEMENT } \\
\text { Unclassified-Unlimited } \\
\text { Subject Category: } 23 \\
\text { Available electronically at http://gltrs.grc.nasa.gov } \\
\text { This publication is available from the NASA Center for AeroSpace Information, 443-757-5802 }\end{array}$} \\
\hline
\end{tabular}

\section{SUPPLEMENTARY NOTES}

\section{ABSTRACT}

The application of Oil-Free technologies (foil gas bearings, solid lubricants and advanced analysis and predictive modeling tools) to advanced turbomachinery has been underway for several decades. During that time, full commercialization has occurred in aircraft air cycle machines, turbocompressors and cryocoolers and ever-larger microturbines. Emerging products in the automotive sector (turbochargers and superchargers) indicate that high volume serial production of foil bearings is imminent. Demonstration of foil bearings in APU's and select locations in propulsion gas turbines illustrates that such technology also has a place in these future systems. Foil bearing designs, predictive tools and advanced solid lubricants have been reported that can satisfy anticipated requirements but a major question remains regarding the scalability of foil bearings to ever larger sizes to support heavier rotors. In this paper, the technological history, primary physics, engineering practicalities and existing experimental and experiential database for scaling foil bearings are reviewed and the major remaining technical challenges are identified.

\section{SUBJECT TERMS}

Turbomachinery; Bearings; Gas turbines; Propulsion

\begin{tabular}{|c|c|c|c|c|c|}
\hline \multicolumn{3}{|c|}{ 16. SECURITY CLASSIFICATION OF: } & \multirow{2}{*}{$\begin{array}{l}\text { 17. LIMITATION OF } \\
\text { ABSTRACT } \\
\text { UU }\end{array}$} & \multirow{2}{*}{$\begin{array}{l}\text { 18. NUMBER } \\
\text { OF } \\
\text { PAGES } \\
15\end{array}$} & \multirow{2}{*}{$\begin{array}{l}\text { 19a. NAME OF RESPONSIBLE PERSON } \\
\text { STI Help Desk (email:help@ sti.nasa.gov) } \\
\text { 19b. TELEPHONE NUMBER (include area code) } \\
\text { 443-757-5802 }\end{array}$} \\
\hline $\begin{array}{l}\text { a. REPORT } \\
U\end{array}$ & $\begin{array}{l}\text { b. ABSTRACT } \\
U\end{array}$ & $\begin{array}{l}\text { c. THIS } \\
\text { PAGE } \\
\text { U }\end{array}$ & & & \\
\hline
\end{tabular}



